Omni-Akuatika, 12 (3): 21-28, 2016
ISSN: 1858-3873 print / 2476-9347 online
Research Article

\title{
Pakan Ikan Alternatif Berbahan Baku Lokal untuk Calon Induk Ikan Gurami (Osphronemus gouramy)
}

\author{
Sri Marnani, Taufik Budhi Pramono \\ Fakultas Perikanan dan IImu Kelautan, Universitas Jenderal Soedirman
}

Corresponding author : srimarnanisuwarto@yahoo.com.

\begin{abstract}
The aims of this study was to get local raw material of feed fish able to improve growth and development of gonads and composition of the artificial feed and feed supplement that can improve the reproductive performance of gouramy fish. The method used is the method of completely randomized. The research was used completly randomized design with four treatments and four repetition. The treatmens tested were four kinds, pellet commercial $(60 \%)$ additional sprouts mung bean (Phaseolus radiatus $L$ ), fruit peel papaya (Carica papaya) and cabbage (Brassica oleracea $L$ ) by $40 \%$, and a pelleted commercial $(100 \%)$ as control. Absolute growth ranges from $6-425 \mathrm{~g}$, the relative growth of 3.7 to $22.1 \%$, the growth day $1-7,1 \mathrm{~g} /$ day, feed efficiency from 7.8 to $29.33 \%$, GSI 0.1 to $1.1 \%$ and $\mathrm{HSI} 0.8$ to $1.7 \%$. Temperatures ranging from $23-31,5^{\circ} \mathrm{C}, \mathrm{pH} 6.6$ to 7.5 , Oxygen $5.0-6.2$ ppm , ammonia $0-0.25$ ppm. Supplemental feed mixture (40\%) and commercial pellets (60\%) can improve the growth and reproductive performance brood gouramy. Results of measurement of temperature, $\mathrm{pH}$ and ammonia still qualify live gouramy.
\end{abstract}

Keywords : alternative fish feeds, brood, Osphronemus gouramy

\section{Pendahuluan}

Ikan Gurami merupakan ikan air tawar yang memiliki nilai ekonomis penting dan komoditas unggulan di wilayah Banyumas. Untuk memenuhi kebutuhan induk berkualitas dan peningkatan produksi benih diperlukan manajemen pemeliharaan calon induknya. Salah satu komponen penting dalam usaha budidaya ikan utamanya pemeliharaan calon induk ikan sangat ditentukan oleh mutu pakan yang diberikan. Mutu pakan yang baik untuk calon induk dapat mendukung potensi reproduksinya hingga kualitas telur dan benih yang dihasilkan.

Peningkatan mutu pakan calon induk dapat dilakukan dengan pengkayaan pakan atau melakukan kombinasi penambahan pakan pellet dengan bahan baku pakan lokal baik dari hewani (Syandri et.al., 2008) maupun nabati (Listiowati dan Pramono, 2007) sebagai alternatif pakan ikan.

Pemanfaatan bahan baku pakan nabati seperti kecambah kacang hijau (Phaseolus radiatus $\mathrm{L}$ ), kulit buah pepaya (Carica papaya) dan kubis (Brassica oleracea L) untuk pakan alternatif sebagai bahan pakan tambahan ikan gurami dalam manajemen pakan ikan belum banyak dimanfaatkan dan dikaji. Pemanfaatan bahan baku pakan nabati tersebut relatif murah dan mudah disediakan serta sesuai dengan kesukaan ikan gurami akan pakan nabati.

Defri dan Wijarnako (2010) melaporkan bahwa tepung kecambah kacang hijau memiliki kandungan protein $16,14 \%$, lemak $11,45 \%$ karbohidrat $2,44 \%$ kadar air $7,09 \%$ dan abu $2,21 \%$ serta vitamin E. Kulit buah pepaya memiliki kandungan protein sebesar 25,85\%, dan serat kasar $12,51 \%$ serta berbagai kandungan vitamin. Kulit buah pepaya juga memiliki enzim papain termasuk dalam enzim protease yang berfungsi menghidrolisa ikatan peptida pada protein (Purnama, 2007). Selanjutnya kubis dalam per $100 \mathrm{~g}$ memiliki energi $103 \mathrm{~kJ}$ (25kcal), karbohidrat 5,8 g, serat 2,5 g, Lemak 0,1 g, Protein 1,28 g, Thiamine (Vit. B1) $0,061 \mathrm{mg}(5 \%)$, Riboflavin (Vit. B2) $0,040 \mathrm{mg}$ (3\%),Niacin (Vit. B3) 0,234 mg (2\%),Asam pantotenat (B5) 0,212 mg (4\%), Vitamin B6 0,124 mg (10\%), Folat (Vit. B9) $53 \mathrm{mg}(13 \%)$,Vitamin C $36,6 \mathrm{mg}(61 \%$,) Kalsium $40 \mathrm{mg}$ (4\%),Besi 0,47 mg (4\%),Magnesium 12 mg (3\%),Fosfor $26 \mathrm{mg}$ (4\%), Kalium $170 \mathrm{mg}$ (4\%),dan Seng 0,18 mg (2\%) (USDA Nutrient database).

Pakan calon induk terkait dengan nutrisi yang diperlukan dalam rangka peningkatan pertumbuhan dan kinerja reproduksi atau 
perkembangan gonad. Kinerja reproduksi ikan didukung adanya kerja internal organ-organ reproduksi (hati, gonad dan visceral) dan pendukung lainnya dalam gametogenesis serta kerja hormon (Pramono, 2010; Mylonas et.al., 2015). Perkembangan gonad ikan juga dapat dilihat dari perubahan-perubahan yang terjadi melalui pengukuran indeks pertumbuhan morfoanatomi baik dari segi morfologi (panjang dan berat), anatomi (gonad, hati dan visceral) (Sulistyo, 2005).

Berdasarkan permasalahan tersebut, maka dalam rangka pemanfaatan bahan pakan alternatif nabati kecambah kacang hijau, kulit buah pepaya dan kubis sebagai pakan calon induk ikan Gurami perlu diteliti lebih lanjut. Penelitian ini bertujuan untuk mendapatkan bahan pakan tambahan dan komposisi yang dapat meningkatkan pertumbuhan dan perkembangan gonad ikan gurami

\section{Metode Penelitian}

Penelitian dilaksanakan di Laboratorium Riset Fakultas Perikanan dan IImu Kelautan, Unsoed. Bahan penelitian adalah calon induk ikan gurami betina (Osphronemus gouramy) dengan ukuran 1000 - $3000 \mathrm{~g}$ yang diperoleh dari pembudidaya ikan gurami di Desa Pliken
Kecamatan Sokaraja Banyumas. Calon induk dipelihara di kolam bundar dengan diameter $172 \mathrm{~cm}$ tinggi air $100 \mathrm{~cm}$ atau volume sebesar 1875 L lengkap dengan aerasi dengan kepadatan 4 ekor per kolam.

Calon induk ikan gurami dipelihara selama 60 hari dan diberi perlakuan pakan pellet komersial dicampur pakan tambahan kecambah kacang hijau (Phaseolus radiatus $\mathrm{L}$ ), kulit buah pepaya (Carica papaya) dan kubis (Brassica oleracea L), dan pellet komersial sebagai kontrol. Setiap hari dilakukan pergantian air sebanyak $30-50 \%$ dari total volume kolam pemeliharaan.

Rancangan yang digunakan adalah Rancangan Acak Lengkap dengan 4 (empat) perlakuan dan 4 (empat) kali ulangan. Setiap ekor calon induk ikan merupakan satu ulangan. Perlakuan yang diujikan meliputi perlakuan (A) Pemberian Pakan pellet $60 \%$ dan kubis $40 \%$; perlakuan (B) Pemberian Pakan pellet $60 \%$ dan kecambah 40\%; perlakuan (C) Pemberian Pakan pellet $60 \%$ dan pepaya $40 \%$ serta perlakuan (D) Pemberian pakan pellet $100 \%$. Hasil analisis proksimat pakan yang diujikan kepada calon induk ikan Gurami dapat dilihat pada Tabel 1.

Tabel 1. Hasil analisis proksimat pakan yang diujikan pada calon induk ikan Gurami

\begin{tabular}{lrrrrr}
\hline \multicolumn{1}{c}{ Bahan Pakan } & \multicolumn{1}{c}{ Air (\%) } & \multicolumn{1}{c}{ Abu (\%) } & Protein (\%) & Lemak (\%) & Karbohidrat (\%) \\
\hline Kubis & 8,53 & 5,05 & 28,42 & 9,05 & 48,95 \\
Pepaya & 8,12 & 4,5 & 33,25 & 7,33 & 46,8 \\
Kecambah & 6,82 & 3,33 & 26,85 & 7,9 & 55,1 \\
Pellet & 8,86 & 6,14 & 38,16 & 10,02 & 36,82 \\
\hline
\end{tabular}

Variabel penelitian diukur setiap 7 hari yang meliputi : Pertumbuhan Mutlak (b $. \mathrm{H}=\mathrm{Wt}$ - W0); Laju pertumbuhan harian $\mathrm{LPH}=(\mathrm{Wt}-$ $\mathrm{W} 0) / \mathrm{t}$; Laju pertumbuhan relatif LPR $(\%)=(\mathrm{Wt}$ - W0)/W0 x 100, Gonadosomatik Indeks (GSI) $(\%)=\mathrm{Bg} / \mathrm{Bt} \times 100$ dan Hepatosomatik Indeks (HSI) $\mathrm{HSI}(\%)=\mathrm{Bh} / \mathrm{Bt} \times 100$.

\section{HASIL}

\section{Pertumbuhan mutlak}

Hasil analisis Anova terlihat bahwa pertumbuhan mutlak calon induk gurami dengan pakan kombinasi pellet dan berbagai sayuran memberikan hasil yang berbeda nyata. Berdasarkan hasil uji lanjut dengan Uji Beda
Nyata Terkecil (BNT), menunjukkan bahwa perlakuan A (pellet $60 \%$ + kubis $40 \%$ ) tidak berbeda nyata dengan perlakuan B (pellet $60 \%$ + kecambah kacang hijau 40\%) dan C (pellet $60 \%$ + pepaya $40 \%$ ). Perlakuan B ((pellet $60 \%$ + kecambah kacang hijau 40\%) berbeda nyata dengan perlakuan $\mathrm{C}$ (pellet $60 \%$ + pepaya $40 \%$ ) dan perlakuan D (100\% pellet komersial). Perlakuan pemberian pakan kombinasi pellet dan pakan tambahan (perlakuan A, B dan C) berbeda nyata dengan perlakuan pemberian $100 \%$ pellet (D) (Gambar 1). Berturut-turut pertumbuhan mutlak dari yang tertinggi adalah perlakuan pakan (A) sebesar $425 \mathrm{~g}$, perlakuan $\mathrm{B}$ sebesar $350 \mathrm{~g}$, dan perlakuan (C) $325 \mathrm{~g}$ serta perlakuan (D) sebesar $60 \mathrm{~g}$. 


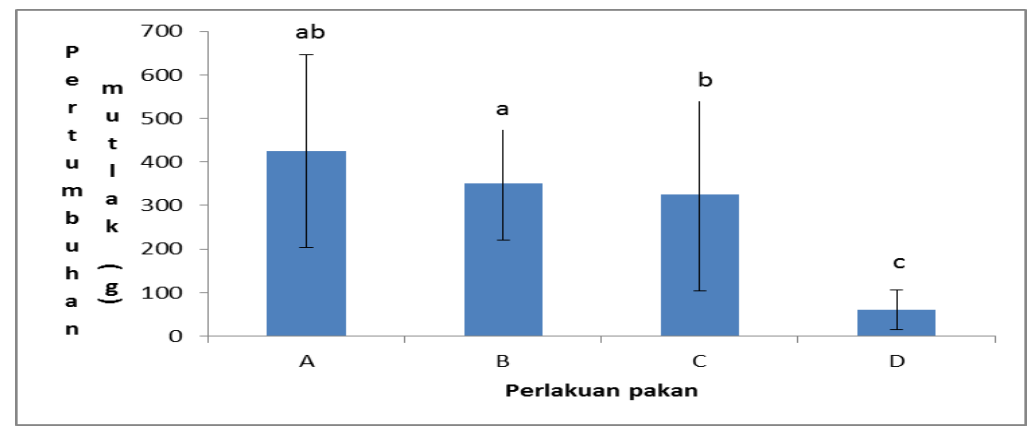

Gambar 1. Laju pertumbuhan mutlak calon induk ikan gurami selama penelitian Keterangan $A$ (pellet $60 \%+$ kubis $40 \%$ ), B (pellet $60 \%$ + kecambah kacang hijau $40 \%$ ), C (pellet $60 \%$ + pepaya $40 \%$ ) dan $\mathrm{D}$ (pemberian pellet $100 \%)$

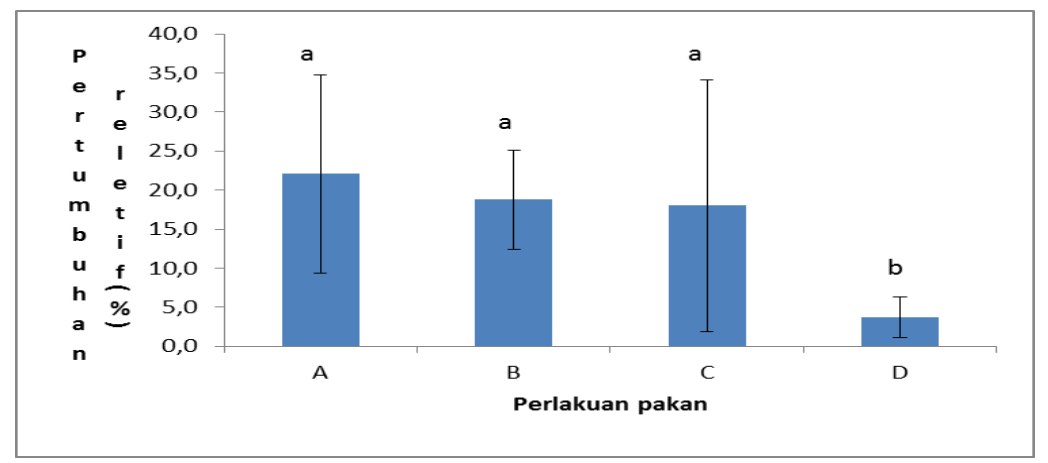

Gambar 2. Grafik batang pertumbuhan relatif calon induk gurami (\%). Keterangan : A (pellet $60 \%+$ kubis $40 \%$ ), B (pellet $60 \%$ + kecambah kacang hijau 40\%), C (pellet $60 \%$ + pepaya $40 \%$ ) dan D (pemberian pellet 100\%)

Hasil analisis anava pertumbuhan relatif calon induk gurami dengan pakan kombinasi pellet dan berbagai pakan tambahan sayuran memberikan hasil yang berbeda nyata. Hasil uji lanjut dengan Uji Beda Nyata Terkecil menunjukkan bahwa perlakuan pemberian pakan kombinasi antara pellet $60 \%$ dan pakan tambahan $40 \%$ masing-masing baik kubis, kecambah dan pepaya $40 \%$ tidak berbeda nyata, namun dibandingkan dengan perlakuan pemberian pakan pellet $100 \%$ menghasilkan pertumbuhan relatif yang berbeda nyata (Gambar 2). Berturut-turut pertumbuhan relatif dari yang tertinggi adalah perlakuan pakan $(A)$ sebesar $22,1 \%$, perlakuan pakan B $(18,8 \%)$, perlakuan pakan $\mathrm{C}$ sebesar $18 \%$ dan perlakuan pakan (D) sebesar 3,7\%.
Hasil analisis Anova pertumbuhan harian calon induk Gurami dari perlakuan terlihat bahwa pertumbuhan harian calon induk gurami dengan pakan kombinasi pellet dan berbagai sayuran memberikan hasil yang berbeda nyata. Berdasarkan uji lanjutan Beda Nyata Terkecil (BNT), menunjukkan bahwa perlakuan kombinasi pemberian pakan pellet $60 \%$ dengan berbagai macam sayuran (kubis, kecambah dan pepaya) sebesar $40 \%$ tidak berbeda nyata sedangkan perlakuan pemberian pakan pellet $100 \%$ menghasilkan pertumbuhan harian yang berbeda (Gambar 3). Berturut-turut pertumbuhan harian dari yang tertinggi adalah perlakuan (A) sebesar 7,1 g/hari, perlakuan pakan (B) 5,8 g/hari, perlakuan pakan (C) 5,4 $\mathrm{g} /$ hari dan perlakuan pakan D sebesar $1 \mathrm{~g} /$ hari. 


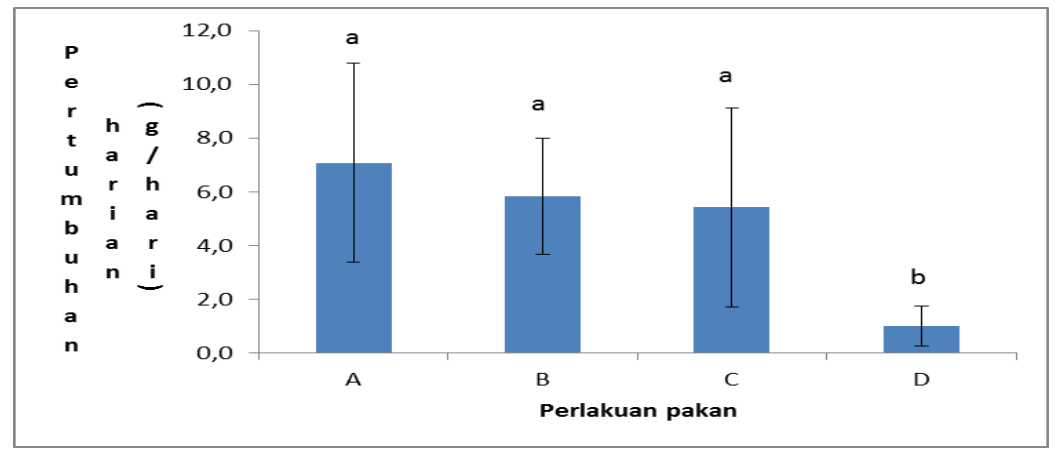

Gambar 3. Grafik batang pertumbuhan harian calon induk gurami selama penelitian ( $\mathrm{g} / \mathrm{hari}$ ). Keterangan : A (pellet 60\% + kubis 40\%), B (pellet 60\% + kecambah kacang hijau 40\%), C (pellet $60 \%$ + pepaya $40 \%$ ) dan $\mathrm{D}$ (pemberian pellet $100 \%$ ).

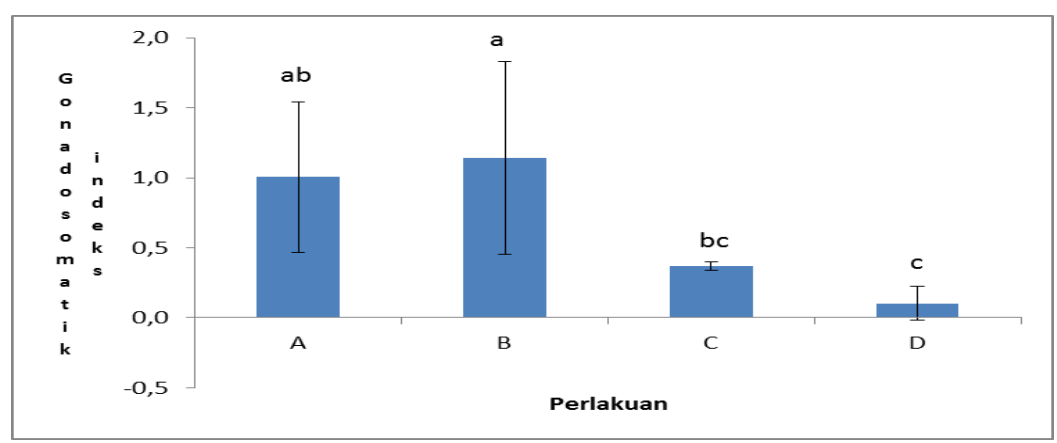

Gambar 4. Grafik batang GSI calon induk ikan gurami selama penelitian. Keterangan : A (pellet $60 \%$ + kubis $40 \%$ ), B (pellet $60 \%$ + kecambah kacang hijau $40 \%$ ), C (pellet $60 \%$ + pepaya $40 \%$ ) dan D (pemberian pellet $100 \%$ )

\section{Pertumbuhan gonad}

Pertumbuhan gonad dihitung dengan mengukur Gonado Somatik Index (GSI). Nilai GSI dari perlakuan berdasarkan analisis Anova memperlihatkan bahwa nilai GSI calon induk gurami dengan pakan kombinasi pellet dan berbagai sayuran memberikan hasil yang berbeda nyata (F Hitung $>F$ Tabel). Hasil uji BNT menunjukkan bahwa perlakuan pemberian kombinasi pakan pellet $60 \%$ dan berbagai pakan tambahan kubis, kecambah dan pepaya masing-masing sebesar $40 \%$ tidak berbeda nyata, sedangkan perlakuan pemberian pakan pellet $100 \%$ menghasilkan nilai GSI yang berbeda (Gambar 4).
Nilai Indeks Hepato Somatic (IHS)

Kinerja reproduksi ikan digambarkan
dengan jelas pula dengan indeks
hepatosomatik (IHS) yaitu suatu nilai dalam persen sebagai hasil dari perbandingan berat hati dengan berat tubuh ikan dikalikan $100 \%$ (Sulistyo et al. 2000). Pada penelitian ini, hasil analisis Anova menunjukkan nilai IHS calon induk gurami dengan pakan kombinasi pellet dan berbagai pakan tambahan sayuran memberikan hasil yang berbeda nyata ( $F$ Hitung > F Tabel). Berdasarkan analisis uji lanjut BNT, menunjukkan bahwa perlakuan pemberian kombinasi pakan pellet $60 \%$ dengan kecambah kacang hijau $40 \%$ berbeda nyata dengan pakan kombinasi lainnya dan pemberian $100 \%$ pakan pellet komersial. (Gambar 5). 


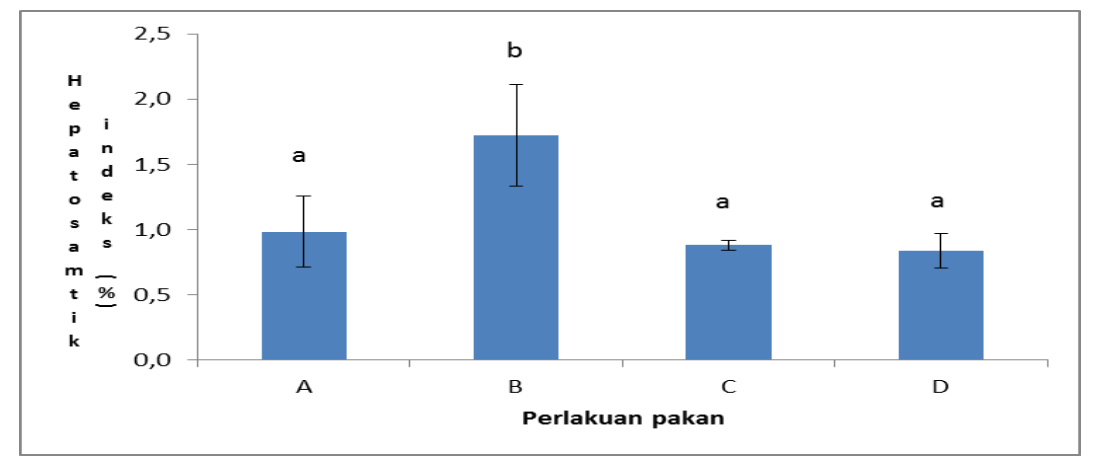

Gambar 5. Grafik HSI calon induk gurami selama penelitian. Keterangan : A (pellet $60 \%+$ kubis $40 \%$ ), B (pellet $60 \%$ + kecambah kacang hijau $40 \%$ ), C (pellet $60 \%$ + pepaya $40 \%$ ) dan D (pemberian pellet $100 \%)$.

\section{Diskusi}

Faktor pakan sangat menentukan pertumbuhan ikan. Jumlah dan mutu pakan akan mempengaruhi pertumbuhan ikan baik pertumbuhan somatik maupun gonadik. Hasil analisis proksimat pakan uji pada penelitian ini (Tabel 1), menandakan bahwa adanya ketersediaan kebutuhan protein yang memadai bagi calon induk ikan Gurami. Kandungan protein pakan tambahan berupa kubis mengandung protein sebesar $28,42 \%$, kecambah $(26,85 \%)$ dan pepaya $(33,25 \%)$. Hal ini menunjukan bahwa pakan tambahan tersebut menambah ketersediaan protein pakan yang diberikan pada calon induk ikan gurami selain pakan pellet komersial $(38,16 \%)$.

Pertumbuhan somatik pada penelitian ini meliputi pertumbuhan mutlak, relatif dan pertumbuhan harian. Pertumbuhan mutlak, relatif dan harian pada penelitian ini, keseluruhan parameter ujinya menunjukkan bahwa perlakuan A dengan kombinasi pakan pellet $60 \%$ dan kubis $40 \%$ mampu meningkatkan bobot tubuh calon induk ikan Gurami dibandingkan perlakuan lainnya selama pemeliharaan.

Kandungan protein yang terbesar dari pakan tambahan atau kombinasi pakan yang disediakan dalam penelitian ini adalah kulit pepaya $(33,25 \%)$, akan tetapi hasil pertumbuhan dan pertumbuhan gonadnya paling kecil dibanding pemberian pakan tambahan lain seperti kecambah kacang hijau dan kubis. Artinya kombinasi pakan yang diberikan mampu meningkatkan pertumbuhan somatik dan gonadik. Penelitian ini juga menjelaskan bahwa pakan tidak hanya ditentukan oleh kandungan protein semata, tetapi juga oleh elemen nutrisi lainnya seperti lemak, karbohidrat, vitamin, mineral yang dapat diperoleh dari sumber pakan lainnya.
Mokoginta dan Subandiono (2005) menyatakan bahwa adanya kandungan karbohidrat dapat dijadikan sumber energi dimana dapat berperan sebagai pengganti sebagian energi dari protein untuk pertumbuhan.

Pakan tambahan berupa kubis, kecambah kacang hijau dan pepaya mengandung elemen nutrisi lainnya seperti vitamin $C(\mathrm{Vc})$, vitamin $\mathrm{E}(\mathrm{Ve})$, mineral dan enzim yang dapat membantu proses absorpsi nutrisi di saluran pencernaan. Kemampuan dalam absorpsi atau menyerap nutrisi akan meningkatkan energi yang dimanfaatkan untuk pertumbuhan baik somatik maupun gonadik (Affandi, 2007). Pakan tambahan kubis mengandung vitamin dan beberapa mineral (USDA), kecambah kacang hijau mengandung vitamin E (Defri dan Wijarnako,2010) dan pepaya mengandung vitamin $\mathrm{C}$ dan enzim papain yang membantu proses hidrolisa ikatan peptida protein (Purnama, 2007). Keberadaan pakan tambahan alternatif menjamin ketersediaan vitamin dan mineral untuk langsung dapat dikonsumsi oleh calon induk ikan Gurami dibandingkan pakan pellet komersial.

Pakan pellet komersial dibuat tentunya menyediakan unsur nutrisi lain utamanya $V_{c}$ dan Ve, akan tetapi diduga vitamin tersebut mengalami kerusakan baik yang diakibatkan oleh cahaya, panas, oksigen, transportasi maupun penyimpanan. Davey et.al. (2000) menyatakan bahwa Vc dan Ve termasuk jenis yang sangat mudah rusak oleh oksigen, cahaya, panas. Sementara vitamin E (Ve) sangat sensitif terhadap perubahan $\mathrm{pH}$ (Bramley et al., 2000). Sifat tersebutlah yang mendasari untuk diberikan dalam bentuk segar, agar vitamin-vitamin tidak banyak hilang.

Kebutuhan vitamin khususnya vitamin $\mathrm{C}$ (Vc) dan vitamin $E(V e)$ dalam ransum pakan ikan sangat penting. Vitamin $\mathrm{C}$ dalam pakan 
dibutuhkan sebagai antioksidan yang berfungsi melindungi kolesterol dari kerusakan akibat terjadinya oksidasi (Marzuqi, et.al., 2015). Kerusakan kolesterol karena oksidasi selanjutnya akan mempengaruhi proses biosintesis hormon estrogen untuk pertumbuhan (Darias et.al., 2011). Vitamin E ( $\alpha$-tokoferol) adalah salah satu unsur nutrien yang harus ada dalam pakan, karena dibutuhkan sebagai bahan struktur somatik, gonadik dan penentu kualitas telur. Apabila oosit atau telur dalam perkembangannya tidak memperoleh vitamin dalam jumlah yang cukup , maka telur relatif kecil dan derajat penetasan rendah, selanjutnya sintasan rendah (Darias et.al.,2011).

Nilai GSI dapat digunakan untuk mendeteksi keadaan perkembangan ovari, periode reproduksi dan peningkatan berat atau bentuk gonad. Nilai GSI tergantung pada ukuran badan dan berkorelasi positip dengan total panjang, total berat dan tingkat perkembangan gonad (Sulistyo et.al. 2000; Pramono 2010). Penelitian ini menunjukkan bahwa nilai GSI calon induk Gurami berkisar antara $0,1-1,1 \%$. Menurut Gratiana, et al. (2009), nilai GSI induk ikan gurami yang dapat dipijahkan akan terus meningkat setiap minggunya dengan kenaikan per minggunya berturut-turut yaitu $1.794 \%, 2,312 \%, 2,562 \%$ dan $4,468 \%$. Hal ini membuktikan bahwa ikan gurami penelitian masih membutuhkan waktu satu untuk dapat dipijahkan.

Pemberian kombinasi pakan 60\% pakan pellet komersial dan $40 \%$ pakan tambahan kecambah kacang hijau dalam penelitian ini ternyata mampu meningkatkan perkembangan gonad sebesar $1,1 \%$. Hal ini diindikasikan adanya peran $V_{c}$ dan $V_{e}$ dalam pengaturan pertumbuhan gonadik. Tang dan Affandi (2001), mengemukakan bahwa Ve dapat ditambahkan ke dalam pakan untuk mempercepat fase pembentukan folikel telur. Defisiensi vitamin E pada ikan dapat menyebabkan kandungan lemak di hati dan otot berkurang, juga bisa menyebabkan penyakit distrofi otot, degenerasi lemak hati, anemia, pendarahan dan berkurangnya fertilisasi. Pada masa reproduksi, $\alpha$-tokoferol akan didistribusikan ke jaringan adiposa oosit. Tokoferol disimpan dalam jaringan adipose dan daging. Selama vitelogenesis kandungan tokoferol dalam tubuh menurun sampai kirakira $10 \%$ pada tingkat kematangan gonad (Yulperius et.al., 2003). Kecambah kacang hijau mempunyai kelebihan dibanding dengan jenis kacang-kacangan yang lain, karena kandungan tripsin inhibitornya sangat rendah, dan paling mudah dicerna (Anggrahini, 2007). Kandungan a-tokoferol kecambah yang diinkubasi selama 36 jam sebesar $0,21 \mu \mathrm{g} / \mathrm{g}$ dan diinkubasi selama 48 jam sebesar 0,53 $\mu \mathrm{g} / \mathrm{g}$ (Anggrahini, 2007). Kelebihan pemberian a-tokoferol juga tidak baik karena dapat menyebabkan kematian pada ikan dan penurunan pertumbuhan, karena $\alpha$-tokoferol bersifat toksik dalam hati (Yulfiperius, 2003). Maka dari itu, harus tercukupi asupan vitamin E yang berada dalam pakan atau ditambahkan pada pakan.

Kinerja reproduksi ikan digambarkan dengan jelas pula dengan indeks hepatosomatik (IHS) (Sulistyo et al. 2000). Hati merupakan organ tubuh yang berperan penting dalam proses reproduksi karena terlibat dalam proses pembentukan kuning telur sampai terbentuk vitelogenin. Pada hati ikan betina tersimpan lemak dalam jumlah besar selama tahap previtelogenik dan cadangan ini dihabiskan selama vitelogenesis (Lucifora et al. 2002). Organ ini umumnya merupakan suatu kelenjar yang kompak, berwarna merah kecoklatan yang tersusun oleh sel-sel hati (hepatosit) (Fujaya 2002). Nilai IHS calon induk ikan gurami yang tertinggi terdapat pada perlakuan pemberian kombinasi pakan $60 \%$ pellet komersial dan $40 \%$ kecambah kacang hijau sebesar $1,7 \%$. Artinya terdapat deposit energi sebesar 1,7\% untuk perkembangan ovari. Hendri (2010), menyatakan hal yang sama bahwa adanya peningkatan IHS menandakan adanya pengumpulan materi energi yang cukup besar di organ hati untuk memproduksi nutrien pembentukan sel telur berupa vitelogenin. Aktifitas vitelogenin menyebabkan nilai $\mathrm{HSI}$ dan GSI ikan meningkat. Pada kematangan gonad, hati akan menunjukkan perbedaan sturktuk, warna dan berat. Hal ini sebagai akibat produksi vitelogenin (Sjafei, et al., 1992).

Vitamin $C$ maupun $E$ sangat penting untuk proses reproduksi. Kadar Vc dan Ve yang dibutuhkan ikan berbeda beda tergantung dari jenis dan umur ikan (Lim et.al., 2007). Dalam penelitian ini, tidak dilakukan pengukuran kandungan $V_{c}$ dan Ve. Hakim et al., (2007) melaporkan bahwa penambahan Vc (120 mg/Kg pakan), Ve (34 mg/Kg pakan) dan selenium $(0,2 \mathrm{mg} / \mathrm{Kg}$ pakan) ke dalam pakan untuk penampilan reproduksi ikan nila (Oreocromis niloticus) pada pakan, memberikan hasil yang terbaik dalam diameter telur, HSI, GSI. Diameter telur untuk perlakuan kombinasi Vitamin C, E dan selenium rerata lebih dari $2000 \mu$ sedangkan untuk kelompok kontrol rerata kurang dari $1500 \mu$, untuk nilai HSI rerata adalah $3,942 \pm 1,487$, untuk nilai GSI rerata adalah 2,662 $\pm 0,491$. Yulfiperius et al. (2010) juga melaporkan bahwa penambahan Ve $(220 \mathrm{mg} / \mathrm{Kg})$ pada pakan untuk penampilan 
reproduksi ikan lalawak jengkol (Barbodes sp.), memberikan hasil terbaik dalam nilai GSI yaitu sekitar 12\% dan fekunditas sekitar 20566 butir dibandingkan dengan pemberian vitamin $E$ sebanyak 210, 240 dan $248 \mathrm{mg} / \mathrm{Kg}$ pakan, akan tetapi untuk nilai HSI semua perlakuan tidak berbeda nyata.

\section{Kesimpulan}

Bahan pakan tambahan berupa kubis, kecambah kacang hijau dan kulit pepaya yang dikombinasikan pakan pellet komersial dapat meningkatkan pertumbuhan dan kematangan gonad calon induk ikan gurami.

\section{Daftar Pustaka}

Affandi, R. 2007. Fisiologi Pencernaan Ikan. Fakultas Perikanan dan IImu Kelautan IPB, Bogor.

Anggrahini, S., 2007. Pengaruh Lama pengecambahan Terhadap Kandungan $\alpha$-Tokoferol dan Senyawa Senyawa Proksimat Kecambah Kacang Hijau (Phaseolus radiatus L.). Jurnal Agritech. 27 (IV): 152-157.

Dabrowski, K. and J.H. Blom. 1994. Ascorbic Acid Deposition In Raibowtrout (Oncorhynchus mykiss) Eggs and Survival of Embryos. Comparative Biochemistry and Physiology. 108A : 129-135.

Darias, M. J., Mazurais, D., Koumoundouros., Cahu, C.L and Zambonino-Infante, J. L. 2011. Overview of vitamin D and C requirements in fish and their influence on the skeletal system. Aquaculture 315: 49-60..

Davey, M.W., Montagu, M.V., Inze, D., Sanmartin, M., Kanellis, A., Smirnoff, N., Benzie, I.J.J., Strain, J.J., Favell., D. Dan Fletcher, J. 2000. Plant L-ascorbic acid: chemistry, function, metabolism, bioavailabilty and effect of processing. J. Sci. Food Agric. 80: 825-860.

Fujaya, Y. 2002. Fisiologi Ikan : Dasar Pengembangan Teknologi Perikanan. DIKTI. Jakarta. 181 hal.

Hakim, A. El-Greisy,Z. El-Ebiary, E. 2007. Synergistic Effect of Vitamins $C$ and $E$ and Selenium on the Reproduction Performance of Nile Tilapia, Oreochromis niloticus. Journal of Applied Scince Research: 564-573

Halimah, S.R dan E.S. Heruwati, 1997. Pertumbuhan dan Sintasan Gurami
Dalam Sistem Resirkulasi Dengan Pemberian Pakan Yang Berbeda. Jurnal Penelitian Perikanan Indonesia III (1): 65-77.

Hendri, Afrizal. 2010. Manipulasi Fotothernal dalam Memacu Pematangan Gonad Ikan Senggaringan (Mystus nigriceps). Tesis. IPB, Bogor.

Izquierdo, M.S., H.Fernandez-Palacios and A.G.J. Tacon. 2001. Effect of Broodstock Nutrition On Reproduction Performance of Fish. Aquaculture 197 : 25-42.

Lim C., Aksoy M. L., Welker T. and Klesius P., 2007, Growth, immune response and resistance to Streptococcus iniae of Nile Tilapia fed diets containing various levels of vitamin $C$ and $E$, United State Department of Agricultural Research Services.

Listiowati, E., dan Taufik Budhi Pramono. 2014. Potensi Pemanfaatan Daun Singkong (Manihot utilisima) Terfermentasi Sebagai Bahan Pakan Ikan Nila (Oreochromis sp). Berkala Perikanan Terubuk 42 (2) : 3-10.

Lucifora LO, Menni RC, Escalante AH. 2002. Reproductive ecology and abundance of the sand tiger shark Carcharias taurus from the Southwestern Atlantic. ICES Journal of Marine Science. 59 : 553 561.

Marzuqi, M., I.N. A. Giri., T. Setiadharma., R. Andamari., W. Andriyanto dan N.W. Widyastuti. 2015. Penggunaan pakan prematurasi untuk peningkatan perkembangan gonad pada calon induk ikan Bandeng (Chanos chanos Forskal). Jurnal Riset Akuakultur 10 (4) : 519-530.

Mokoginta, I., dan Subandiono. 2005. Metabolisme karbohidrat pada ikan gurami (Osphronemus gouramy) yang mengkonsumsi pakan mengandung kromium $\left(\mathrm{Cr}^{3+}\right)$. Laporan Penelitian Dasar. Institut Pertanian Bogor. Bogor.

Mylonas, C.C., Fostier, A., and Zanuy S. 2010. Broodstock management and hormonal manipulations of fish reproduction. General and Comparative Endocrinology $165: 516-534$.

Pramono, T.B. 2010. Profil Reproduksi Ikan Senggaringan (Mystus nigriceps) : Dasar Domestikasi dan Budidayanya. Tesis. 
Institut Pertanian Bogor. Bogor. Indonesia.

Sandnes, K., Y. Ulgenes., O.R. Braekkan., F. Utne. 1994. The Effect of Ascorbic Acid Supplementation In Broodstock Feed On Reproduction of Rainbowtrout (Salmo gairdneri). Aquaculture 43 : 167-177.

Sjafei, D.S., M.F.Rahardjo., R. Affandi., M. Brojo dan Sulistiono. 1992. Fisiologi Reproduksi Ikan II : Reproduksi Ikan. PAU-IImu Hayat. Institut Pertanian Bogor.

Sulistyo I, P Fontaine, J Rincarh, JN Gardeur, $\mathrm{H}$ Migaud, B Capdeville and $\mathrm{P}$ Kestemont. 2000. Reproductive Cycle and Plasma Level of Steroid in Male Eurasian perch (Perca fluviatilis). Aquatic Living Resources 13 (2). 99-106.

Tang, M.U., dan R. Affandi. 2001. Biologi Reproduksi Ikan. P2KP2 UNRI. Riau, 165 hal.

Yulfiperius. 2003. Pengaruh Kadar Vitamin E dalam Pakan Terhadap Kualitas Telur Ikan Patin (Pangasius hypothalamus). Jurnal Ikhtiologi Indonesia Volume 3, Nomor 1. Fakultas Perikanan dan IImu Kelautan IPB, Bogor.

Yulfiperius, Toelihere, M. Affandi, R. Subardja,D. 2010. Kebutuhan Vitamin C dan E (VCE) di dalam Pakan untuk Memperbaiki Performans Reproduksi Ikan Lalawak Jengkol (Barbodes $s p$ ). Institut Pertanian Bogor, Bogor. 